\title{
A conceptual model to estimate ungauged losses in river water accounting
}

\author{
Paydar, Z. and A.I.J.M. Van Dijk \\ CSIRO Land and Water/Water for a Healthy Country Flagship \\ Email: zahra.paydar@csiro.au
}

\begin{abstract}
There is much uncertainty associated with water accounting in the complex lowland parts of the river systems across the Murray Darling Basin (MDB), where diversions and extractions, losses to flood plains and wetlands and groundwater recharge can all occur within the same reach and at the same time. Flood plain losses include water harvesting and overbank flow going to the wetlands and subsequently being evapotranspired. This water is generally not metered and hence there is no good quality historical data available. Monitoring and quantifying these losses are challenging. Modeling the processes causing these losses on the flood plain is an alternative way of quantifying these losses.
\end{abstract}

This paper presents a simple water loss accounting model that tracks water and quantifies processes occurring on a flood plain in a river reach (Figure 1). These include diversions for irrigation, on-farm storage (OFS) and use, flood plain harvesting, overbank flow to the wetlands and return flow to the river. Given initial estimates of such parameters as irrigation efficiency, OFS volume and area, overbank flow threshold and fraction of return flows, optimum values of these parameters are found by minimising the residual error term for the water accounting period. The model attributes some of the unaccounted losses to flood plain water harvesting to the on-farm storages for later use, and estimates return flows from the wetlands and irrigation areas.

The model was applied to a number of lower river reaches of the Gwydir, Namoi and Murrumbidgee catchments for the period of 1990-2006. Model performance was satisfactory for almost all reaches. The attribution of losses to on-farm storages and flood plains/wetlands reduces the unattributed losses and improves the estimation of losses in the lower parts of the river system. The improvements are substantial where there are large volumes of water diverted to on-farm storages. An important consideration would be the interaction with the groundwater that is being ignored currently in the model.

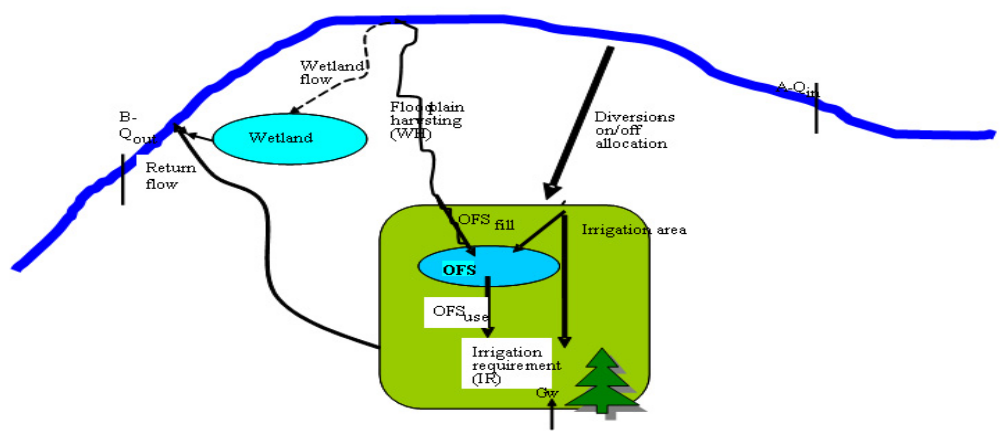

Figure 1. A schematic representation of flood plain processes

Keywords: water accounting, river hydrology, uncertainty in water balance 


\section{INTRODUCTION}

River water balance accounts are important to assess how well we understand the water balance, how much of the total volume of water is measured and how much is used and what proportions are not accounted for. They make it possible to assess how well the river water balance can be closed by combining data and models and how well accounts compare with historic fluxes. A monthly reach by reach water account of all major river systems in the Murray Darling Basin was developed and used to build up catchment and basin water accounts (Kirby et al. 2008). These monthly accounts indicate where our understanding of the system is worse and hence where more measurements or research would improve our hydrological description and decrease uncertainties in water balance estimates. Full details of the water balance accounting methods and the river model uncertainty assessment can be found in Kirby et al. (2008) and Van Dijk et al. (2008), respectively. The general conclusion from those studies was that there is more uncertainty associated with complex lowland parts of the river system, where diversions and extractions, losses to flood plains and wetlands and groundwater recharge can all occur within the same reach and at the same time, whereas streamflow gauging can be challenging (Van Dijk et al. 2008). Large unattributed losses were reported in the water accounts for some parts of the Basin. Internal losses probably represent the greatest source of uncertainty in the lower parts of river systems across the basin where there are often large ungauged floods, water harvesting and distributary flows. Additional metering and remote sensing observations interpreted for water use should help reduce uncertainties (Van Dijk et al. 2008).

One area of improvement is to consider on-farm storages (OFS) and flood plain water harvesting in the modeling of losses. Flood plain losses (other than recorded diversions and direct extractions) include water harvesting (or land surface diversions) and overbank flow going to the flood plains/wetlands and being evapotranspired. Land Surface Diversion (LSD) can be a significant part of total diversions in some parts of the Basin and are defined as the diversion of runoff or flood into on-farm storage or for direct irrigation, thus preventing it from entering a water course or infiltrating into the flood plain (Bewsher Consulting, 2006). The harvesting of water reduces the amount of water reaching or returning to rivers, decreasing the amount of water available to meet downstream demands. This water is not metered and hence there is no good quality historical data available. Quantifying LSDs is challenging and inadequacy of current methods of quantifying these losses poses limitations on existing and proposed policies for managing such diversions. Modeling the processes causing losses on the flood plain is an alternative way to quantify these losses. Here we introduce a conceptual model that considers the land surface diversions in the river water accounting, thus attributing losses to productive or environmental uses.

\section{METHODOLOGY}

\subsection{Model description}

A simple water loss accounting model for a reach between upstream (point A) and downstream (point B) is illustrated in Figure 1. It includes diversions for irrigation, on-farm storage (OFS) and use, flood plain harvesting (LSD), overbank flow to the wetlands and return flow to the river. Irrigation diversions can be either on- or off-allocations. On-allocation diversion is the water that is ordered by the irrigator to satisfy their crop water requirement or management needs, usually during the irrigation period. This water is debited from the irrigators' water share for the year. Off-allocation or supplementary water is water that is extracted from the river during a surplus flow period. This water is not debited from the irrigators' water share. The area covered by this monthly water accounting is the area served by the river reach which includes irrigated fields (considered in one lumped irrigation area) and all the wetlands (occasionally) receiving water from the reach $\mathrm{AB}$. For each reach, a monthly accounting sheet with the water balance components was set up in MS Excel $^{\mathrm{TM}}$. Given the stream gauging records at the two end points (A and B), the rate of evaporation from open water, the irrigation requirements (based on remote sensing or other methods) and use, the model keeps track of changes in OFS during and after the irrigation season. Starting calculations with the minimum water in OFS as initial condition, if the amount of irrigation diverted (accounting for losses) is more than irrigation requirements, the extra water is stored in OFS $\left(\mathrm{OFS}_{\text {fill }}\right)$ as on- or off-allocation water. If the amount of diversion is not enough to satisfy the requirements, then the water left in OFS is used for irrigation. Figure 2 shows a schematic diagram of this loss model, where it interacts with the overbank model (Figure 3). At any time during the year, if the flow in the river is more than a threshold $\left(\mathrm{Q}_{\mathrm{th}}\right)$, there will be overbank flow, some of it being used for "flood plain harvesting" (water harvesting going to fill on farm storages-OFS overbank) and some will be going to the wetlands ( $\mathrm{F} 1$ fraction of overbank flow). Flood plain storage for each month $\left(\mathrm{S}_{\mathrm{t}}\right)$ is calculated by adding to the previous month's storage $\left(\mathrm{S}_{\mathrm{t}-1}\right)$ all inflows as rainfall and overbank flow and subtracting all outflows (evapotranspiration from flood plains /wetlands and inundated areas). Wetland ET 
might be comprised of two components: Open water evaporation (Eo) from inundated areas (Inu_A) and actual ET (ET wetland) from wetland areas (Wet_A). Any inflows that fill the wetland in excess of drainable capacity of the system are assumed to flow back to the river (Return_wet) but with a delay of one month, using a simple linear model with F2 fraction of the storage at time t:

Return_wet $=\mathrm{F} 2 * \mathrm{St}$

Total return flow to the river ( $\mathrm{Q}$ return) is the sum of the water returning from the wetland (Return wet) and the irrigation return flow (Return_IR) as a fraction (F3) of diverted water for irrigation (Div). This overbank flow model interacts with the Loss model for calculation of return flows and updating the OFS volumes as in Figure 2 .

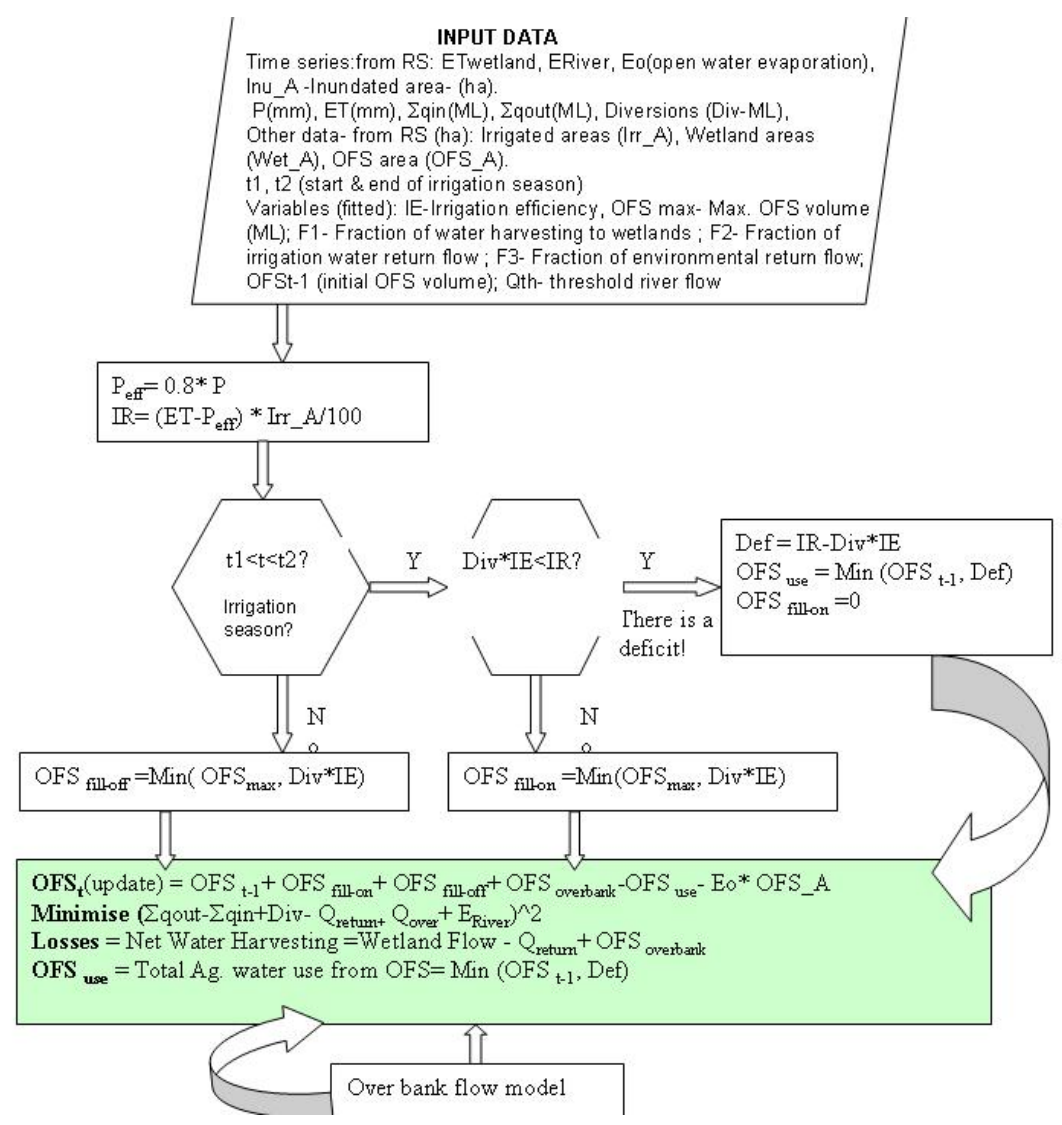

Figure 2. Schematic diagram of the loss model $\left(\mathrm{OFS}_{\mathrm{t}}=\right.$ Current volume of OFS, OFS ${ }_{\text {use }}=$ water used from OFS; OFS ${ }_{\text {fill-on, }}$ OFS ${ }_{\text {fill-off, }}$ OFS ${ }_{\text {overbank }}=$ Volume of water used to fill the OFS from on-allocation, offallocation and over bank flow water; IR $=$ Irrigation requirement, Def $=$ Irrigation deficit, Div $=$ diversions, $\mathrm{t} 1$ and $\mathrm{t} 2$ define the start and end of the irrigation season and IE = Irrigation efficiency, $\mathrm{P}=$ rainfall)

For each month, the water balance of the reach would be:

$Q_{\text {in }}+Q_{\text {trib }}+Q_{\text {runoff }}-Q_{\text {out }}-Q_{\text {distrib }}-Q_{\text {divert }}-Q_{\text {evap }}+\Delta S+Q_{\text {loss }}+Q_{\text {return }}+e=0$

Where $Q_{i n}, Q_{\text {trib }}$, and $Q_{\text {runoff }}$ are inflows from upstream, a tributary and direct runoff into the reach, and $Q_{\text {out }}$, $Q_{\text {distrib }}, Q_{\text {divert }}, Q_{\text {evap, }}$ and $Q_{\text {return }}$ are outflows to the downstream, a distributary, diversions, direct evaporation from the reach and return flow to the river respectively. $\Delta S$ is the change in storage; $e$ is the error term and $Q_{\text {loss }}$ represents the water harvesting and flow to wetlands. Significant additional terms may exist in some reaches, such as flows to or from groundwater. These are currently not considered. 
Given initial estimates of some parameters (i.e. irrigation efficiency, OFS volume limits and area (if not available through remote sensed data), $\mathrm{Q}_{\text {thres }}$ and fraction of return flows from wetlands (F2) and from irrigation (F3), optimum values of these parameters are found by minimising the error term (sum of square of residuals) for the water accounting period. The output would be losses including total overbank flow and flood plain harvesting, return flow and water going to the wetlands, as well as water filling up the OFS from different allocation or harvesting sources and the amount of the return flow going back to the river.

\subsection{Model inputs}

There are several time series data as input to this model, some derived from spatial data. These are: precipitation for the river reach (e.g. SILO; Jeffrey et al., 2001); measured stream flow from upstream; tributary and direct runoff into the reach (measured or modelled); measured stream flow downstream; distributary outflow; diversions from the river; actual evapotranspiration from wetlands and irrigation areas. The actual evapotranspiration estimates for the basin (Guerschman et al., 2008) were produced on a $0.01^{\circ}$ national grid using remote sensing methods and are based on a combination of estimates from a) high resolution satellite temperature measurements for 1990-1999, and b) satellite measured greenness and soil wetness for 2000-2006. Evaporation from open water was calculated following McJannet et al. (2008), by combining mass transfer and energy budget principles with SILO climate data used as input. The PenmanMonteith method was used with an adjustment to the amount of energy available for evaporation based on changes in heat storage within the water-body (McJannet et al., 2008). Water body width and depth (as required for open water evaporation estimation) was estimated differently for irrigation channels, streams, reservoirs as detailed in Kirby et al. (2008). Other input data consist of areas of irrigated land and wetlands and the time the irrigation season starts and ends in the region.

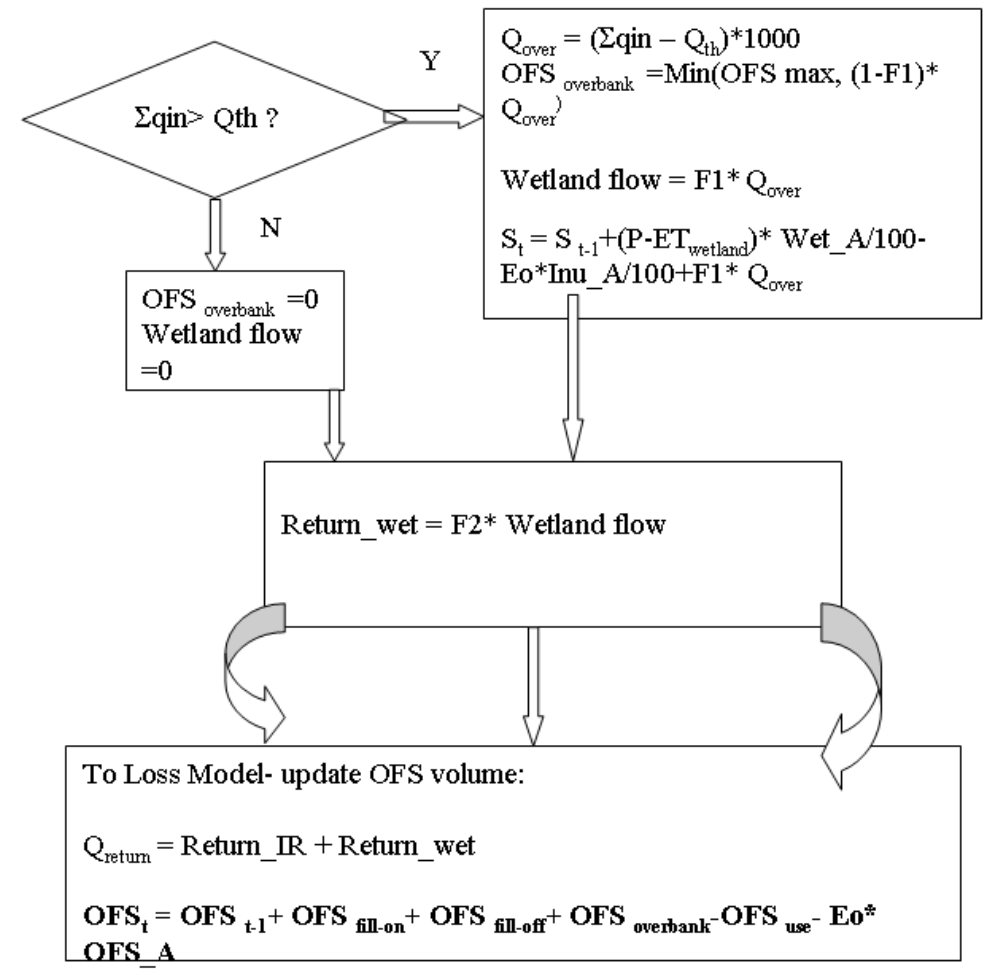

Figure 3. Overbank flow model

\subsection{Model testing}

To test this conceptual model, a total of seven river reaches in lower parts of the Gwydir and Murrumbidgee and Namoi catchments, most of them with large ungauged losses, were chosen and the model was applied to quantify losses. Model performance was compared against previous studies where OFS was not considered. The key difference between the approach of Kirby et al. (2008) and the approach followed here is the 
consideration of OFS in modeling losses and return flows in combination to wetland losses. The input data for those reaches were sourced from the previous study in those regions (Kirby et al., 2008) for the period 1990-2006.

Model performance was assessed by comparing the Nash-Sutcliffe model efficiency (NSME; Nash and Sutcliffe, 1970) in explaining the variance in downstream observed flows by the model, as well as the mean absolute annual residuals and monthly residuals in the river water balance account.

\section{RESULTS AND DISCUSSION}

The summary results of model predictions and performance are shown in Table 1. The unattributed losses or gains, total water harvested to flood plains and water directed to the on-farm storages as well as model efficiency (NSME) as a model performance indicator are listed for the seven river reaches considered. To see the advantage of including OFS in the modelling of losses, the unattributed losses after applying the loss model were compared with the previous study (Kirby et al., 2008) results without OFS accounting. Almost all predictions (except Gwydir@ Millewa) showed some degree (1\%-92\%) of reduction in the residual unattributed gains and losses.

Table 1. Losses and associated predictions for river reaches in MDB.

\begin{tabular}{|c|c|c|c|c|c|c|c|c|}
\hline \multirow[t]{2}{*}{ River reach } & \multirow{2}{*}{$\begin{array}{l}\text { Inflow } \\
\text { GL/yr }\end{array}$} & \multirow{2}{*}{$\begin{array}{l}\text { Divers } \\
\text { ion } \\
\text { GL/yr }\end{array}$} & \multicolumn{2}{|c|}{$\begin{array}{l}\text { Annual } \\
\text { unattributed } \\
\text { losses or gains } \\
\text { (GL) }\end{array}$} & \multirow{2}{*}{$\begin{array}{l}\text { Water } \\
\text { harvested- } \\
\text { Flood plain } \\
(\mathrm{GL})\end{array}$} & \multirow{2}{*}{$\begin{array}{l}\text { Water } \\
\text { directed } \\
\text { to OFS } \\
\text { (GL) }\end{array}$} & \multirow{2}{*}{$\begin{array}{l}\text { Monthly } \\
\text { unattributed } \\
\text { losses\&(gains) } \\
\text { (GL) }\end{array}$} & \multirow[t]{2}{*}{ NSME } \\
\hline & & & $\begin{array}{l}\text { loss } \\
\text { model }\end{array}$ & $\begin{array}{l}\text { (Kirby } \\
\text { et al. } \\
2008)\end{array}$ & & & & \\
\hline $\begin{array}{l}\text { Meehi (Gwydir) } \\
(418037- \\
\text { 418055)D/S } \\
\text { Collarenabri }\end{array}$ & $217 / 98$ & 152 & 21 & 100 & 13 & 60 & $15(19)$ & $<0$ \\
\hline $\begin{array}{l}\text { GilGil(Gwydir) } \\
\text { (418027-418052) } \\
\text { @Weemelah }\end{array}$ & $145 / 108$ & 22 & 1 & 10 & 5 & 15 & $6(11)$ & 0.62 \\
\hline $\begin{array}{l}\text { Gwydir(418053- } \\
\text { 418066)@ Millewa }\end{array}$ & $75 / 27$ & 12 & 2 & 0.5 & 33 & 6 & $1(2)$ & 0.28 \\
\hline $\begin{array}{l}\text { Gwydir(418001- } \\
\text { 418004)@Yaraman }\end{array}$ & $689 / 451$ & 84 & 1.5 & 19 & 128 & 38 & $19(30)$ & 0.53 \\
\hline $\begin{array}{l}\text { Namoi(419012- } \\
\text { 419003)@ Narrabri }\end{array}$ & $721 / 640$ & 4 & 36 & 73 & 35 & 3 & $8(7)$ & 0.98 \\
\hline $\begin{array}{l}\text { Namoi(419039- } \\
\text { 419059)@ } \\
\text { Gunidgera }\end{array}$ & $692 / 526$ & 129 & 4 & 18 & 81 & 35 & $10(11)$ & 0.95 \\
\hline $\begin{array}{l}\text { Murrumbidgee } \\
\text { (410040- } \\
\text { 410136)@Maude }\end{array}$ & $1347 / 1020$ & 74 & 133 & 138 & 97 & 27 & $22(18)$ & 0.94 \\
\hline
\end{tabular}

In general when the diversions are large and the volume of water directed to on-farm storages is large, the model reduces the unattributed losses substantially. The model efficiency (NSME) values show reasonably good performance for most reaches. The poor performance for the Gwydir at Collarenabri and Millewa might be due to measurement problems at high flows. Figure 4 shows how the losses (negative flows) at Millewa are dominated by high flows $\left(Q_{\text {in }}\right)$ where the gauging can also be difficult. Accounting for OFS filling (OFS fill) and flood plain water harvesting in the loss model reduces the apparent unaccounted losses $\left(Q_{\text {out }}-Q_{\text {in }}\right)$ and brings the "modeled unattributed losses" closer to the "zero loss"(i.e. x- axis). 


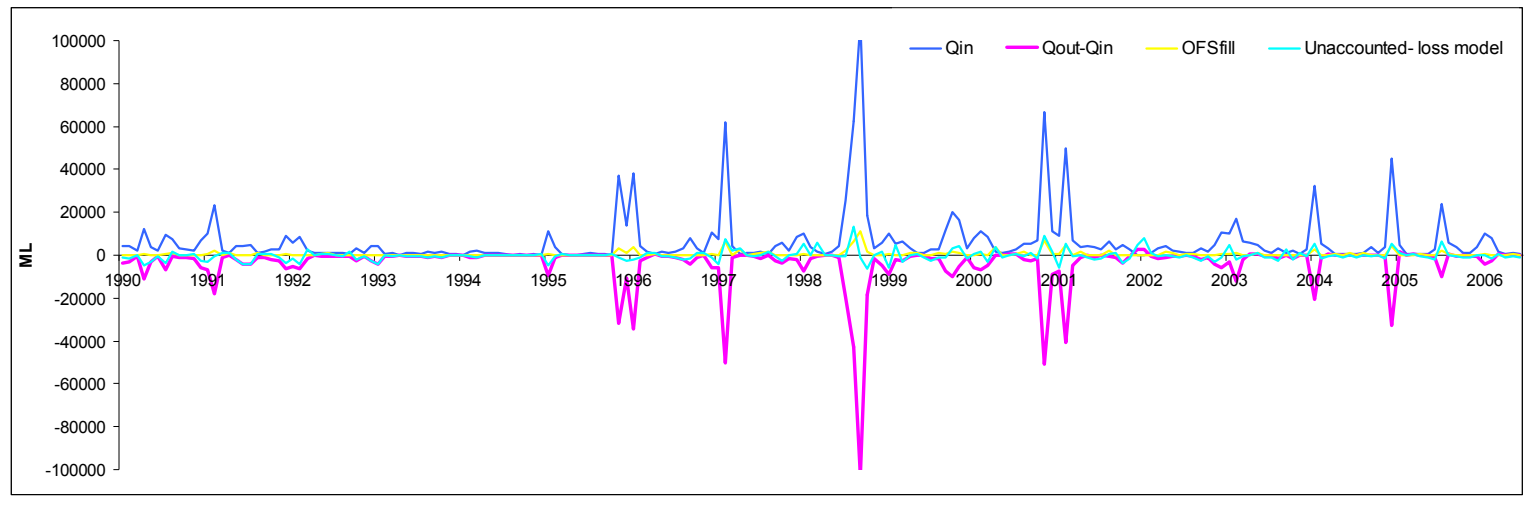

Figure 4. Components of water account in Gwydir- Millewa reach: Inflow $\left(Q_{\text {in }}\right)$; apparent losses $\left(Q_{\text {out }}-Q_{\text {in }}\right)$; OFS filling and unattributed model losses (negative values indicate losses).

Figure 5 shows some of the modelling components for the Gwydir for the Yaraman Bridge reach where the flood plain losses are major components of the losses. The attribution of losses to flood plain and OFS explains most of the apparent losses $\left(Q_{\text {out }}-Q_{\text {in }}\right)$.

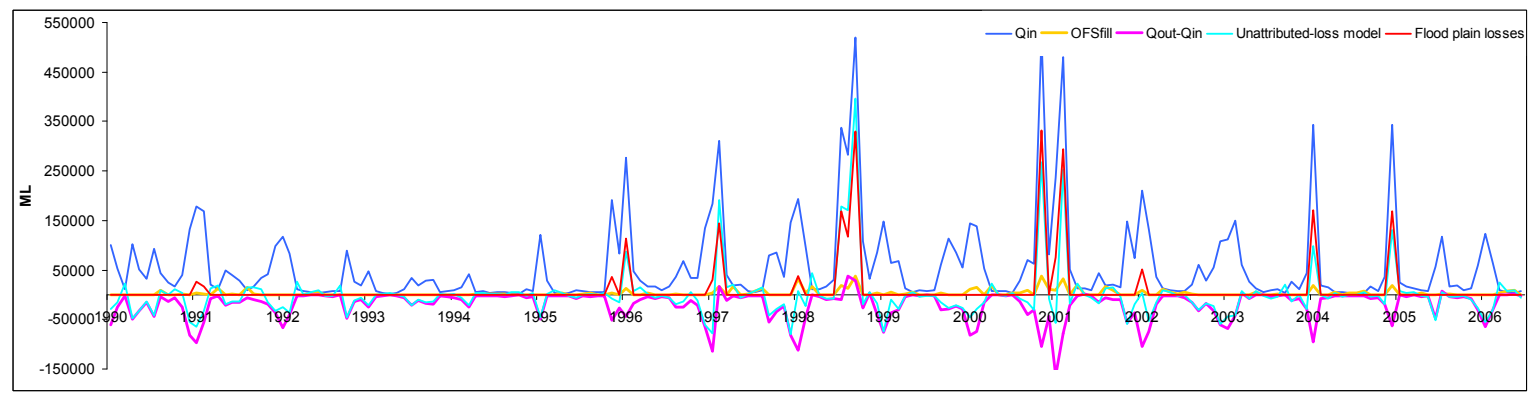

Figure 5. Components of water account in Gwydir- Yaraman Bridge reach: Inflow $\left(\mathrm{Q}_{\text {in }}\right)$; apparent losses $\left(\mathrm{Q}_{\text {out }}\right.$ $\left.-\mathrm{Q}_{\text {in }}\right)$; OFS filling; flood plain losses and unattributed model losses.

Figure 6 compares the predicted flows against the observed flows at the end of the Maude reach in Murrumbidgee. Despite the large unattributed losses in this reach, predictions of the outflow match the observed flow at Maude quite well. Overall the model predictions for most of these lower river reaches considered are reasonably good. The attribution of losses to the flood plains/wetlands and on-farm storages reduced the apparent losses and subsequently the uncertainty in river reach water balance accounting. Some of the remaining unattributed losses might be due to the groundwater exchanges. All these river reaches have some degree of connectivity to the groundwater, but the current version of the model does not account for these exchanges.

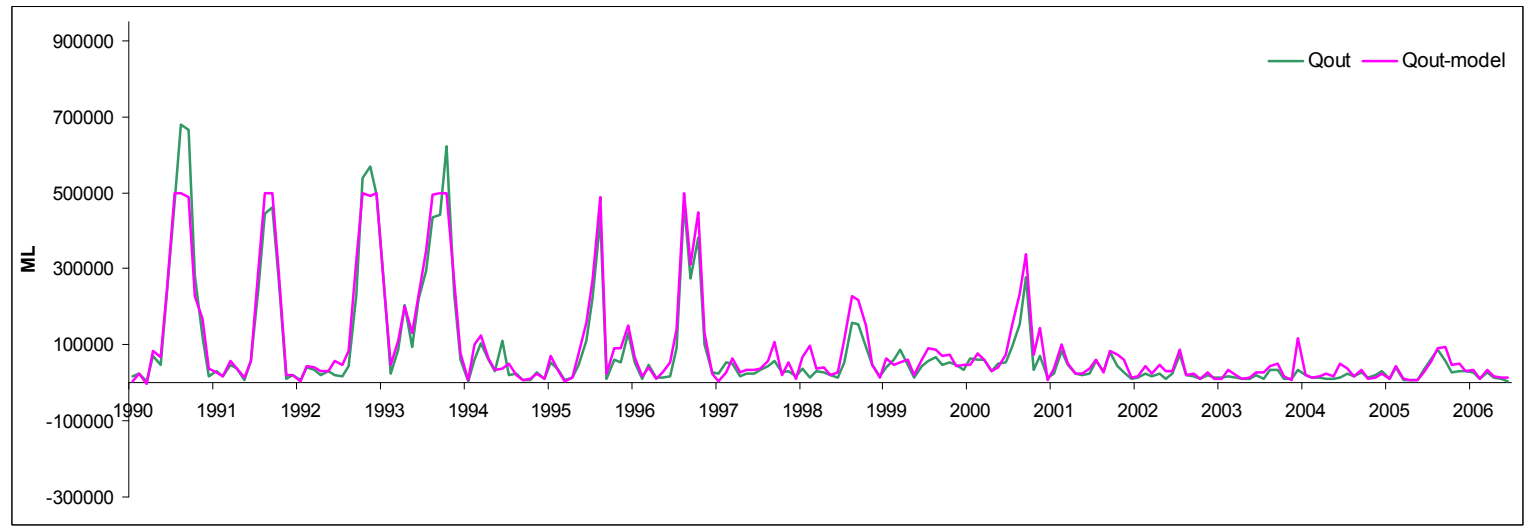

Figure 6. Model prediction vs. observed outflow for Murrumbidgee River @ Maude 


\section{CONCLUSIONS}

A conceptual model was developed for monthly water balance accounts that can account for the losses in the lower parts of the river system. The model can attribute losses to the water diverted to on-farm storages for later use and to the environmental use (flood plains and wetlands) where the accounts are most uncertain. Remote sensing data and other ancillary data (actual evapotranspiration from irrigation areas, flood plains, open water evaporation) are used in the model to further reduce uncertainty in these areas. When the model was applied to seven reaches of lower parts of the Gwydir, Namoi and Murrumbidgee rivers, the results showed that the model performed reasonably well in most of the reaches, reducing uncertainty in unattributed losses/gains. The improvement over the previous accounts is more substantial when the diversions and onfarm storage harvesting are large. More improvements are possible by considering the exchanges with the groundwater and use of direct observations or estimates (e.g. areas of on-farm storages or inundated areas) to constrain or reduce the number of the model parameters used in optimisation.

\section{ACKNOWLEDGMENTS}

Part of this work was funded through the water information research and development alliance between CSIRO's Water for a Healthy Country Flagship and the Bureau of Meteorology.

\section{REFERENCES}

Bewsher Consulting (2006). Land Surface Diversions Status Report. Report to Murray-Darling Basin Commission, Final Report, July 2006.

Guerschman, Juan-Pablo, Albert I.J.M. Van Dijk, Tim R. McVicar, Tom G. Van Niel, Lingtao Li, Yi Liu, Jorge Peña-Arancibia (2008). Water balance estimates from satellite observations over the MurrayDarling Basin. Report of the Murray-Darling Basin Sustainable Yields project.

Jeffrey SJ, Carter JO, Moodie KB and Beswick AR (2001). Using spatial interpolation to construct a comprehensive archive of Australian climate data. Environmental Modelling and Software 16, 309 330 .

Kirby JM, Van Dijk AIJM, Mainuddin M, Peña Arancibia J, Guerschman J-P, Liu Y, Marvanek S, McJannet DL, Paydar Z, McVicar TR, Van Niel TG and Li LT (2008). River water balance accounts across the Murray-Darling Basin, 1990 to 2005. A report to the Australian Government from the CSIRO Murray-Darling Basin Sustainable Yields Project. CSIRO, Australia.

McJannet, D., Webster, I., Stenson, M and Sherman, B. (2008). A method to estimate open water evaporation losses across the Murray Darling Basin. Report of the Murray-Darling Basin Sustainable Yields project.

Nash JE and Sutcliffe JV (1970). River flow forecasting through conceptual models1: A discussion of principles. Journal of Hydrology 10, 282-290.

Van Dijk AIJM, Kirby JM, Paydar Z, Podger G, Mainuddin Md, Marvanek S and Peña Arancibia J (2008). Uncertainty in river modelling across the Murray-Darling Basin. A report to the Australian Government from the CSIRO Murray-Darling Basin Sustainable Yields Project, CSIRO Australia. 